\title{
PEMBUBARAN HIZBUT TAHRIR INDONESIA DITINJAU DARI PERSPEKTIF KEWARGANEGARAAN LIBERAL DAN KEWARGANEGARAAN REPUBLIK
}

\author{
Itok Dwi Kurniawan
}

Dosen PPKn Universitas Sebelas Maret Surakarta.

\begin{abstract}
ABSTRAK
Tujuan artikel ini untuk mengkaji dan menganalisis pembubaran Hizbut Tahrir Indonesia (HTI) ditinjau dari perspektif kewarganegaraan liberal dan kewarganegaraan republik. Jenis penelitian ini termasuk penelitian doktrinal yang mengacu pada sumber data sekunder dan tersier. Jika menganalisisnya menggunakan kewarganegaraan liberal, pembubaran itu tentunya tidak sah, karena Perppu merupakan sarana mengekang atau meniadakan kebebasan, terutama kebebasan berorganisasi. Tetapi bagi kewarganegaraan republikanisme, cita-cita organisasi massa HTI tidaklah sejalan dengan bangsa Indonesia yang menganut Pancasila dan UUD Negara Republik Indonesia Tahun 1945. Jika tidak sejalan dengan cita-cita, bisa dianggap patriotisme anggota HTI sangatlah kurang.
\end{abstract}

\section{Kata Kunci : Hizbut Tahrir Indonesia, Kewarganegaraan Liberal, Kewarganegaraan Republik}

\begin{abstract}
This article aims to review and analyze the dissolution of HizbutTahrir Indonesia (HTI) from the perspective of liberal citizenship and republican citizenship. This type of research includes doctrinal research that refers to secondary and tertiary data sources.If analyzing it uses liberal citizenship, dissolution is certainly not valid, because the Perppu is a means of curbing or negating freedom, especially freedom of organization. But for republicanism citizenship, the ideals of the HTI mass organization are not in line with the Indonesian people who adhere to the Pancasila and the 1945 Constitution of the Republic of Indonesia. If it is not in line with the ideals, it can be considered that patriotism of HTI members is very lacking.
\end{abstract}

Keywords : Hizbut Tahrir Indonesia, Liberal Citizenship, Republican Citizenship 


\section{PENDAHULUAN}

Salah satu keindahan dari demokrasi adalah bahwa ada ruang untuk kelompok yang kita tidak setujui, bahkan kelompok yang kita anggap menghina. Ruang keindahan demokrasi ini oleh Nurcholis Madjid disebut masyarakat madani.

Apakah yang dimaksud masyarakat madani? Definisi mengenainya telah berkembang dari waktu ke waktu. Pada 1994, ilmuwan politik Larry Diamond mendefinisikan masyarakat madani sebagai warga negara yang bertindak secara kolektif dengan cara yang bersifat suka rela, otonom dari negara dan terikat oleh tatanan hukum atau seperangkat aturan bersama (Larry Diamond, 1994: $5)$.

Mereka bisa mengambil berbagai bentuk, termasuk organisasi komersial, seperti kamar dagang, kelompok profesional, kelompok LSM, kelompok pendidikan. Mereka juga dapat mencakup kelompok agama yang bertujuan mempertahankan identitas kolektif atau mempertahankan keyakinan mereka.

Diamond melihat kelompok ini punya peran penting membatasi peran negara dengan mencari perubahan kebijakan atau menuntut akuntabilitas. Dia juga melihat mereka sebagai pendukung pluralisme sehingga dia mengeluarkan berbagai kelompok fundamentalis serta kelompok lain "yang berusaha untuk memonopoli ruang fungsional atau ruang politik dalam masyarakat, mengklaim jalan mereka sebagai satu-satunya jalan yang sah (Ibid, 1994: hal. 7)

Banyak juga ilmuwan yang memiliki pandangan berbeda, terutama mengingat munculnya beberapa kelompok pasca Komunis di Eropa Tengah dan Timur. Ilmuwan tersebut mengakui bahwa kita sulit memahami civil society apabila kita mengabaikan kelompok-kelompok yang sebenarnya punya tujuan kurang konstruktif. Misalnya, jika kita berbicara tentang Eropa Tengah, kita harus menyertakan kelompok Skinhead (berkepala plontos) dan kelompokkelompok lain yang berniat membersihkan negaranya dari etnis tertentu. Jika kita berbicara tentang AS, kita harus menyertakan kelompokkelompok anti-imigran dan rasis.

Di Indonesia, kita tidak bisa bicara masyarakat madani tanpa memasukkan kelompok-kelompok Islam yang mendukung formalisasi syariat Islam dan berniat menggantikan sistem demokrasi dengan pemerintahan Islam. Tujuannya bisa sangat sempit dan diskriminatif; doktrinnya bisa eksklusif, dan untuk beberapa, taktiknya bisa termasuk penggunaan kekerasan. Kunci untuk mempertimbangkan kelompokkelompok ini sebagai masyarakat 
madani adalah apakah mereka melihat diri mereka sebagai jembatan antara warga negara dan negara, dan sebagian besar memang begitu.

Thomas Carothers juga menggarisbawahi bahwa tidak benar pernyataan yang menyatakan bahwa makin aktif masyakarat madani di satu negara, makin kuat demokrasinya. Dia mengutip sebuah studi tentang periode Weimar di Jerman, yang menunjukkan bagaimana jaringan masyarakat madani di sana, pada tahun 1920 dan 1930-an, bisa disusupi dan dimanfaatkan oleh Partai Nazi sehingga akhirnya masyarakat madani tidak melindungi sistem demokratis, tetapi malah menghancurkannya (Thomas Carothers dalam Sidney Jones, 2013: 4 - 5).

Dinamika kehidupan organisasi Islam Hizbut Tahrir Indonesia (HTI) menarik untuk dikaji karena fokus organisasi Islam ini salah satunya berkenaan dengan peranan mereka yang mengagendakanIslam sebagai ideologi utama dalam hal apapun. Walaupun tidak jarang,dalam perjalanannya untuk menyebar luaskankan ideologi tersebut menimbulkan pertentangan antara hubungannya dengannegara atau pandangan terhadap agama lainnya.

Dewasa ini, keberadaan Hizbut Tahrir Indonesia (HTI) menambah jumlah deretan organisasi masyarakat yang bersuara untuk menjunjung revivalisme Islam(Kebangkitan Islamdari keterpurukan, yang menilai dari berbagai fakta ketidakadilan yang telah terjadi dan penyebabnya ditujukan pada systemnegara yang mengatur masyarakat).Hizbut Tahrir Indonesia (HTI) hadir dengan membawa ideologi Islam yang terus didengungkan yaituKhilafah.

Sehingga pada tanggal 19 Juli2017 Pemerintah Indonesia melalui Kementerian Hukum dan HAM secara resmi mencabut status badan hukum ormas Hizbut Tahrir Indonesia (HTI) berdasarkan Surat Keputusan Menteri Hukum dan HAM Nomor AHU30.AH.01.08 Tahun 2017 tentang pencabutan Keputusan Menteri Hukum dan HAM Nomor AHU0028.60.10.2014 tentang Pengesahan Pendirian Badan Hukum Perkumpulan HTI. Pencabutan tersebut dilakukan sebagai tindaklanjut Peraturan Pemerintah Pengganti Undang-undang (Perppu) Nomor 2 Tahun 2017 yang mengubah UU Nomor 17 Tahun 2013 tentang Organisasi Kemasyarakatan (https://id.wikipedia.org/wiki/Pembubara n_Hizbut_Tahrir_Indonesia).

Pembubaran ini dikarenakan aktivitas HTI dinilai mengancam kedaulatan politik negara. HTI mengusung ideologi 
khilafah yang secara garis besar bersifat transnasional, yang berorientasi meniadakan nation state (negara bangsa). Fakta yang ada bahwa 20 negara (termasuk negara yang penduduknya mayoritas Islam seperti Turki, Arab Saudi, Pakistan, Mesir, Yordania dan Malaysia) sudah terlebih dahulu melarang kegiatan HTI di negara mereka (Bayu Dwi Anggono, https://news.detik.com/kolom/3510278/ meninjau-alasan-hukum-pembubaranhti).

Ada 3 (tiga) alasan utama pembubaran HTI oleh Menteri Koordinator Politik Hukum dan Keamanan,menurut Wiranto (Menko Polhukam) yaitu :

1. Sebagai ormas berbadan hukum, HTI tidak melaksanakan peran positif untuk mengambil bagian dalam proses pembangunan guna mencapai tujuan nasional.

2. Kegiatan yang

dilaksanakan HTI terindikasi kuat telah bertentangan dengan tujuan, asas, dan ciri yang berdasarkan Pancasila dan UUD Negara Republik Indonesia tahun 1945 sebagaimana diatur dalam Undang-Undang Nomor 17 Tahun 2013 tentang Ormas.

3. Aktivitas yang dilakukan HTI dinilai telah menimbulkan benturan di masyarakat yang dapat mengancam keamanan dan ketertiban masyarakat, serta membahayakan keutuhan Negara Kesatuan Republik Indonesia (https://id.wikipedia.org/wiki/Pem bubaran_Hizbut_Tahrir_Indonesia)

Berdasarkan uraian diatas Penulis tertarik untuk mengkaji mengenai bagaimana pembubaran Hizbut Tahrir Indonesia ditinjau dari perspektif Kewarganegaraan Liberal dan Kewarganegaraan Republik.

\section{METODE PENELITIAN}

Jenis penelitian yang digunakan dalam penulisan ini adalah penelitian normatif atau doktrinal. Menurut Peter Mahmud Marzuki, semua penelitian yang berkaitan dengan hukum (legal research) adalah selalu normatif(Peter Mahmud Marzuki, 2014 :55-56). Sifat penelitian hukum ini adalah preskriptif.Penelitian hukum dilaksanakan untuk memecahkan isu-isu hukum yang diajukan, dan memberikan preskripsi mengenai apa yang seyogyanya(Peter Mahmud Marzuki, 2014 :130). Dalam penulisan penelitian ini penulis menggunakan dua macam pendekatan, yaitu statute approach and case approach(Peter Mahmud Marzuki, 2014 : 35). Pengumpulan data primer 
dilakukan selama proses pembuatan tuntutan dan persidangan dalam kasus a quo. Sedangkan data sekunder dilakukan melalui studi berbagai jurnal, putusan pengadilan, buku, resolusi internasional dan berbagai referensi bahan hukum terkait.

\section{PEMBAHASAN}

\section{Tunbuhnya Organisasi Massa Berpaham Intoleransi dalam Masyarakat Madani}

Orang Indonesia benar bangga dengan demokrasi mereka, dan berbagai survei yang menunjukkan meningkatnya intoleransi agama dalam masyarakat juga menunjukkan dukungan yang luas bagi sistem demokrasi. Namun, kita juga perlu untuk mengeksplorasi mengapa Indonesia menjadi lahan subur bagi tumbuhnya berbagai organisasi yang dalam berbagai aspek kegiatannya bersifat anti-demokrasi. Salah satu kelompok garis keras dan antidemokrasi yang berkembang adalah Hizbut Tahrir Indonesia (HTI), yang ingin menggantikan sistem demokratik di Indonesia dengan khilafah.

HTI yang pada dasarnya antidemokrasi adalah kasus yang sangat berbeda. HTI adalah organisasi yang sangat hati-hati dengan batas-batas hukum. Mereka tidak menggunakan kekerasan, meskipun kadang-kadang mendukung orang lain yang melakukannya. Tujuannya bersifat revolusioner dan anti-demokrasi, dan salah satu cabang terbesar di dunia ada di Indonesia.

\section{Selayang Pandang Hizbut Tahrir Indonesia}

Hizbut Tahrir yang berarti Partai Pembebasan dalam bahasa Arab, adalah sebuah organisasi internasional yang bekerja untuk pembangunan kembali kekhalifahan, sistem global dari pemerintahan Muslim yang terakhir ada di bawah kerajaan Usmani. Kelompok ini telah hadir setidaknya di 45 negara dan dan memfokuskan upaya rekrutmen di kampus-kampus.

Mereka telah menetapkan tiga tahapan untuk meraih kekuasaan. Pertama, pembinaan (tatsqif). Mereka mengidentifikasi calon anggota. Kedua, berinteraksi dengan masyarakat (tafa'ul). Mereka memperkenalkan anggota komunitas Muslim dengan tujuan organisasi, dengan harapan mereka memberikan dukungan mereka. Ketiga, mengambil-alih kekuasaan (istilamu alhukmi). Hal itu bertujuan membangun jaringan pemerintah di bawah kekhalifahan baru (Mohamed Nawab Mohamed Osman, 2010: hal. 737). 
Hal ini mendorong anggotanya untuk mencari dukungan dari kalangan pemerintah dan militer. Pada masa-masa awal organisasi, tahun 1960, aliansi ini menghasilkan serangkaian kudeta yang gagal di Yordania, Suriah, dan Mesir. Pada akhir 1970-an, partai diperluas ke Amerika Serikat, Inggris, dan Australia, dan cabang Indonesia didirikan melalui koneksi dengan anggota cabang Australia. Pusatnya berada di Bogor, di kampus IPB, mereka mempertahankan kehadiran yang kuat sampai hari ini.

Dari tahun 1980-an hingga reformasi, kelompok ini adalah organisasi klandestin. Barulah pada tahun 2000 mereka menjadi organisasi terbuka dan relatif telah berkembang pesat sejak itu, meskipun persyaratan keanggotaan yang ketat menjadikan mereka sebuah organisasi elit yang kurang dikenal di masyarakat luas. Suatu survei dari Lembaga Survey Indonesia (LSI) pada tahun 2006 menunjukkan bahwa hanya $3 \%$ (tiga persen) dari responden mengenal nama Hizbut Tahrir atau tahu tentang kegiatannya, padahal $18 \%$ (delapan belas persen) yang tahu tentang Front Pembela Islam (FPI).

HTI membuat titik budi daya pemimpin pemerintahan di tingkat lokal dan nasional, dan merekrut orang di akademi pemerintah, seperti Institut Pemerintahan Dalam Negeri (IPDN).
Salah satu keberhasilan penting rekrutmen mereka adalah mantan Menteri Kesehatan, dr. Siti Fadillah Supari, yang tur bukunya mengklaim flu babi adalah buatan manusia tersebut disponsori oleh HTI. Selain itu, kecurigaan terhadap laboratorium Barat dan perusahaan farmasi mencerminkan ekspose ajaran HTI. Dorongan dari ajaran-ajaran ini adalah bahwa Barat bertentangan dengan Islam. Bahwa pemerintah Barat dan perusahaan multinasional berusaha melemahkan Islam dan mencuri sumber daya kaum Muslim.

HTI juga pernah bergabung dengan Muhammadiyah dalam permohonan untuk mengakhiri BP Migas dengan alasan bahwa badan tersebut adalah alat kepentingan asing. HTI telah menjadi kekuatan di banyak kampus karena mereka mencoba membatasi perdebatan dan bersikeras pada tema sendiri, yakni Barat dan kapitalisme adalahmusuh. Di samping isu-isu yang bersifat polemis, HTI juga pandai menggerakkan para simpatisan untukmelakukan demonstrasi jalanan, yang lebih ditujukan kepada orang awam - penolakan pencabutan subsidi BBM, misalnya. Pada umumnya, aksi macam ini selalu berlangsung baik, disiplin dan damai. 
HTI juga sangat strategis dalam pendekatan mereka di Aceh dan Papua. Tsunami tahun 2004 memberikan peluang bagi banyak organisasi garis keras untuk mengembangkan basis di Aceh, HTI tidak terkecuali, dimulai dengan kampus di Banda Aceh dan secara bertahap bergerak ke Lhokseumawe dan Aceh Tengah. Ketika di DPRA diadakan rapat dengar pendapat tentang qanun (peraturanDaerah Aceh) yang berkaitan dengan pelaksanaan syariah, HTI selalu hadir sehingga meskipun jumlahnya kecil, kehadiran mereka punya pengaruh signifikan terhadap perdebatan. Di Papua, HTI juga telah aktif bergerak melalui Jayapura di Papua dan melalui organisasi Al-Fatih Kaaffah Nusantara(AFKN) di Papua Barat. Bersama dengan organisasi-organisasi berbasis Jawa lainnya, HTI telah menyebarkan gagasan bahwa para misionaris Kristen telah mengonversi Papua tidak dari kepercayaan penduduk asli, tapi dari Islam dan sekarang saatnya untuk membalik prosesnya (Sidney Jones, 2013: 12 - 13).

Meskipun mengklaim bahwa minoritas akan dilindungi dalam kekhalifahan masa depan, HTIsangat tidak setuju dengan gagasan pluralisme. HTI juga pernah memprotes pameran lintas agama di UIN Syarif Hidayatullah dengan alasan bahwa hal itu sesat. Hizbut Tahrir mungkin menarik "the best and the brightest", tetapi doktrinnya mempromosikan intoleransi.

Jika FPI bisa diibaratkan sebagai otot gerakan Islamis, HTI dan Forum Umat Islam (FUI) adalah otaknya dan agenda keduanya jauh lebih luas dari hanya soal agama. Mereka tahu bagaimana mengajukan hal-hal politik dan sosial supaya menarik untuk masyarakat dan juga bagimana mengangkat hal-hal yang hangat di akar rumput. Mereka pandai membuat aliansi dengan kelompok arus utama (mainstream), seperti Muhammadiyah. Mereka bisamenentukanorang di dalam DPR atau birokrasi yang bersimpati dengan perubahan kebijakan yang mereka inginkan dan mendorong kebijakan itu dari dalam. Mereka memilih isu-isu dengan baik. Mereka hanya bisa menang jika pelawanan dari pemerintah lemah. Jika ada kemauan politik dari pusat yang kuat, mereka selalu kalah.

\section{Kewarganegaraan Liberal}

Pokok pikiran kewarganegaraan ada lima, yaitu (1) kewarganegaraan merujuk pada keanggotaan penuh dan setara di dalam komunitas politik; kewarganegaraan merujuk kepada hak dan kewajiban seorang di dalam komunitas politik; (3) kewarganegaraan 
merujuk kepada otonomi individu di dalam komunitas politik/negara; kewarganegaraan liberal pada dasarnya adalah satu set hak-hak individual; (Robet dan Boli Tobi, 2014, 54) dan (5) merujuk pada rumusan T.H. Marshall, kewarganegaraan adalah “ ... status yang diberikan kepada mereka yang anggota komunitas (T.H. Marshall, 1963, 87). Semua yang memiliki status ini setara kedudukannya terkait hak dan kewajiban yang terkandung dalam status tersebut.

Untuk memahami kewarganegaraan liberal ini, ada dua kunci pokok, yaitu kebebasan sebagai kondisi non-interfence dan hak individual. Pertama, kebebasan sebagai kondisi noninterference atau otonomi penuh merupakan kerangka kebebasan yang dipahami oleh kebebasan dalam artian liberalisme. Kebebasan non-interference ini merupakan sebuah kondisi yang sepenuhnya lepas dari campur tangan pihak di luar dirinya, baik sesama maupun dari institusi politik.

Silsilah ide kebebasan sebagai kondisi non-inteference berasal dari pandangan Thomas Hobbes dan John Locke yang sama-sama menyatakan bahwa sejak dari lahir manusia sudah dalam keadaan bebas dan merdeka. Oleh karena kondisi yang asali ini terus dipertahankan, individu harus menjalin persekutuan untuk membentuk pemerintahan sipil yang bertujuan agar perwujudan kebebasan dalam pencarian kepentingan diri berlangsung secara aman, damai, dan tanpa ancaman yang merugikan keselamatan jiwa dan properti-properti individual lainnya.

Peran negara dalam hubungannya dengan mewujudkan kebebasan noninterference adalah memastikan bahwa setiap orang untuk bebas melakukan apa pun, menguasai sepenuhnya yang telah menjadi miliknya sekaligus otonomi penuh dalam penggunaannya. Meskipun demikian, tetap ada batasannya yang tidak boleh dilanggar, yaitu melanggar hak yang secara sama dimiliki oleh orang lain. Dengan demikian, meskipun kebebasan manusia adalah tujuan utama dalam kewarganegaraan, tetapi dibatasi oleh hukum, hak orang lain, dan norma yang berlaku dalam komunitas politik tempat warga negara tersebut tinggal.

\section{Kondisi}

non-interference

dimungkinkan diakui dalam konteks

kehidupan berbangsa apabila ada pengakuan terhadap hak - hak individu. Perlu diketahui, hak-hak individu dipandang sebagai bagian dari identitas kewarganegaraan seorang yang memungkinkan individu untuk bebas mencari, meraih, memiliki, dan melakukan apa pun yang diinginkannya tanpa sedikit pun ada gangguan dari pihak di luar dirinya. Adapun satu- 
satunya instrumen sosial politik yang berperan dalam membatasi mobilitas kebebasan individu tersebut muncul dari aturan-aturan hukum sipil. Dalam hal ini, hukum sipil seperti membatasi kebebasan individu dalam mengejar kepentingan-kepentingan pribadinya.

Hukum sipil dalam kewarganegaraan liberal dibangun oleh kerangka Lockean yang menyatakan bahwa hukum sipil yang baik sebenarnya tidak diarahkan untuk mengekang kebebasan individu, tetapi diproyeksikan sebagai upaya tercapainya kebebasan secara maksimal. Dengan demikian, fungsi hukum menurut John Locke adalah adalah hukum diposisikan sebagai instrumen sosial-politik untuk penanganan pertikaian dalam proses pencarian kepentingan pribadi.

Berdasarkan hal tersebut, formulasi hukum yang baik adalah memuat rujukan umum dalam menengahi dan menetapkan sanksi terhadap segala pelanggaran hak-hak individu. Selain itu, syarat yang lain adalah membuka peluang seluas-luasnya kepada kebebasan individu dalam mengejar kepentingan pribadinya. Hal ini selaras dengan pendapat Locke yang menyatakan tujuan hukum bukanlah untuk meniadakan atau mengekang, melainkan melestarikan dan memperluas kebebasan (Robet dan Boli Tobi, 2014: 69).

Kedua, pemenuhan hak-hak individual. Pentingnya hak-hak individual dalam kewarganegaraan liberal adalah mengacu pada praktik hidup masyarakat demokratis yang umumnya mendasarkan segala segi perlindungan diri kepada teori hak-hak individual adalah dimensi mental dari seluruh kenikmatan individu (hukum, properti, dan negara) yang dinikmati seorang di dalam negara. Tanpa pandangan dan pengakuan politik atas hak-hak individual, praktik kewarganegaraan pada era modern akan kehilangan seluruh pendasaran logisnya.

\begin{tabular}{|c|c|c|}
\hline Hak Hukum & Hak Politik & $\begin{array}{l}\text { Hak } \\
\text { Partisipasi }\end{array}$ \\
\hline 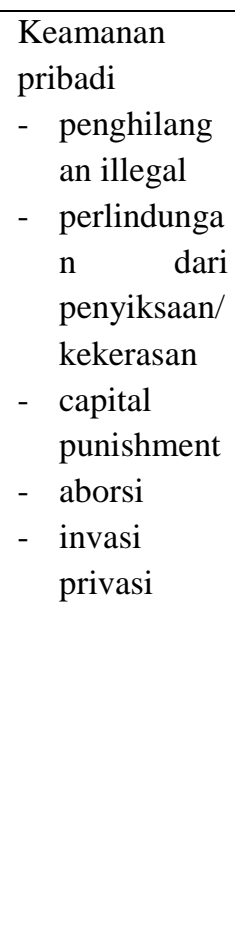 & $\begin{array}{l}\text { Hak untuk } \\
\text { memilih } \\
\text { - hak untuk } \\
\text { menduduki } \\
\text { jabatan } \\
\text { - kebebasan } \\
\text { informasi } \\
\text { - hak untuk } \\
\text { protes }\end{array}$ & $\begin{array}{l}\text { Hak di dunia } \\
\text { kerja } \\
\text { - } \text { hak } \\
\text { mendapat } \\
\text { kan } \\
\text { informasi } \\
\text { ketenagak } \\
\text { erjaan } \\
\text { - hak untuk } \\
\text { meminta } \\
\text { penempat } \\
\text { an kerja } \\
\text { - } \text { hak atas } \\
\text { karya } \\
\text { - perlindun } \\
\text { gan atas } \\
\text { diskrimin } \\
\text { asi } \\
\text { - perlindun } \\
\text { gan kerja }\end{array}$ \\
\hline
\end{tabular}




\begin{tabular}{|c|c|c|}
\hline $\begin{array}{l}\text { Akses dan } \\
\text { proses } \\
\text { keadilan } \\
\text { - hak untuk } \\
\text { diwakili } \\
\text { secara } \\
\text { hukum } \\
\text { - } \text { bantuan } \\
\text { hukum } \\
\text { gratis } \\
\text { - hak untuk } \\
\text { melepaskan } \\
\text { diri dari } \\
\text { tuntutan } \\
\text { hukum } \\
\text { - hak untuk } \\
\text { membantah } \\
\text { tuduhan } \\
\text { - pengadilan } \\
\text { lewat juri } \\
\text { - hak untuk } \\
\text { mengadaka } \\
\text { n kontrak }\end{array}$ & $\begin{array}{l}\text { Hak } \\
\text { berorganisasi } \\
\text { - } \text { hak berpartai } \\
\text { - } \text { hak } \\
\text { perdagangan } \\
\text { /keanggotaa } \\
\text { n dalam } \\
\text { serikat } \\
\text { dagang } \\
\text { - } \text { hak untuk } \\
\text { melancarkan } \\
\text { gerakan } \\
\text { oposisi } \\
\text { - hak untuk } \\
\text { berserikat } \\
\text { dan } \\
\text { melancarkan } \\
\text { protes } \\
\text { hak } \\
\text { kultural/hak } \\
\text { minoritas }\end{array}$ & $\begin{array}{l}\text { Hak } \\
\text { pertimbanga } \\
\mathrm{n} \quad \text { dan/atau } \\
\text { diskriminatif } \\
-\quad \text { hak } \\
\text { tawar- } \\
\text { menawar } \\
\text { secara } \\
\text { kolektif } \\
\text { - hak untuk } \\
\text { bekerja } \\
\text { sama } \\
\text { lintas } \\
\text { etnis }\end{array}$ \\
\hline 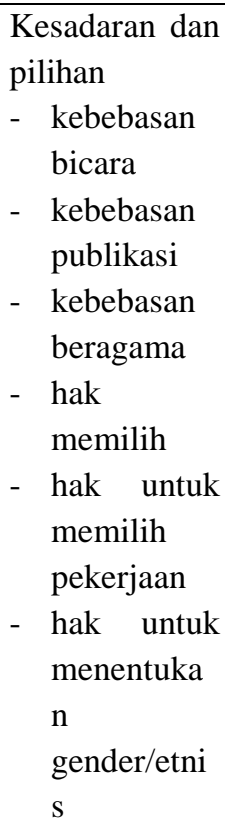 & $\begin{array}{l}\text { Hak } \\
\text { kewarganegara } \\
\text { an } \\
\text { - hak imigrasi } \\
\text { dan } \\
\text { kewarganega } \\
\text { raan } \\
\text { - } \text { naturalisasi } \\
\text { - } \text { suaka politik } \\
\text { - } \text { hak kultural }\end{array}$ & $\begin{array}{l}\text { Kontrol } \\
\text { modal } \\
\text { - } \quad \text { wage } \\
\text { earner } \\
\text { fund } \\
\text { - } \quad \text { kendali } \\
\text { bank } \\
\text { sentral } \\
\text { - } \quad \text { UU } \\
\text { antimono } \\
\text { poli } \\
\text { Keputusa } \\
\text { n strategis }\end{array}$ \\
\hline
\end{tabular}

(Diolah dari Thomas Janoski dan Brian

Grann, dalam Bryan Turner dan Engin F.

Isin, 2002: 15)

\section{Kewarganegaraan}

\section{Republikanisme}

Kewarganegaraan republikanisme muncul karena kritik terhadap terhadap kewarganegaraan liberal. Kritik tersebut meliputi dua hal. Pertama, karena kewarganegaraan liberal terlalu menekankan kepada individu dan pengejaran kepentingan indivisu sehingga menjadikan konsep solidaritas sosial dan kolektivitas tidak terwujud. Kedua, kewarganegaraan liberal mengandaikan hak dan otonomi individu muncul secara terberi begitu saja sebagai akibat situasi politik yang demokratis. Akibatnya, liberalisme tidak dapat mengajukan pandangan alternatif mengenai bagaimana mengefektifkan partisipasi melalui warganya.

Sebelum masuk lebih jauh, ada baiknya kita memperhatikan sekelumit perbedaan antara kewarganegaraan republicanisme dan liberal.

\begin{tabular}{|l|l|l|}
\hline & Liberalisme & $\begin{array}{l}\text { Republikan } \\
\text { isme }\end{array}$ \\
\hline $\begin{array}{l}\text { Asal } \\
\text { kebebasan }\end{array}$ & Alamiah & $\begin{array}{l}\text { Terbentuk } \\
\text { dalam } \\
\text { praktik }\end{array}$ \\
\hline $\begin{array}{l}\text { Pedasaran } \\
\text { kebebasan }\end{array}$ & Metafisika & Sosial \\
\hline $\begin{array}{l}\text { Substansi } \\
\text { politik }\end{array}$ & $\begin{array}{l}\text { Perjuangan } \\
\text { kepentingan } \\
\text { individual }\end{array}$ & $\begin{array}{l}\text { Mencapai } \\
\text { common } \\
\text { good }\end{array}$ \\
\hline $\begin{array}{l}\text { Basis } \\
\text { tindakan }\end{array}$ & Hak & Civic virtue \\
\hline
\end{tabular}




\begin{tabular}{|l|l|l|}
\hline $\begin{array}{l}\text { Subjek } \\
\text { politik }\end{array}$ & Individu & Warga \\
\hline $\begin{array}{l}\text { Siapa itu } \\
\text { warga }\end{array}$ & $\begin{array}{l}\text { Individu dalam } \\
\text { kebebasannya }\end{array}$ & $\begin{array}{l}\text { Warga yang } \\
\text { dideterminas } \\
\text { i oleh virtue }\end{array}$ \\
\hline
\end{tabular}

Tabel di atas diolah dari buku Sosiologi Kewarganegaraan karangan Robertus Robet dan Hendri Boli Tibo, terutama bab Kewarganegaraan Liberal dan Kewarganegaraan Republikanisme. Meskipun ada perbedaan, tetapi dalam konsep kebebasan ada banyak persamaan. Kebebasan dalam republikanisme sebagaimana dinyatakan oleh Macchiavelli sangat dekat dengan otonomi. Kebebasan dalam republikanisme adalah kebebasan nondominasi, bukan kebebasan sebagai kondisi tanpa paksa. Prinsip dasar kebebasan non-dominasi adalah kebebasan bisa hilang atau berkurang bukan karena adanya paksaan atau ancaman, melainkan ada kondisi yang meskipun tanpa ancaman atau paksaan, kebebasan itu hilang dengan sendiri. Contoh klasiknya adalah seorang budak yang bekerja pada tuan yang baik meskipun tidak mengalami paksaan tetapi juga tidak memiliki kebebasan. Kewarganegaraan republikanisme berpangkal tolak pada dua hal, yaitu kebaikan bersama dan civic virtue. Pertama, kebaikan bersama. Inti dasar politik republikanisme adalah konsepnya yang ideal tentang supremasi politik. Disebut ideal karena meletakkan politik di atas kepentingan pribadi dan selalu menekankan bahwa politik itu baik. Bagi republikanisme, politik merupakan arena untuk mencapai kebaikan bersama dalam martabat; meskipun dalam realitanya politik lebih banya diisi kepentingan individual. Jika hal itu terjadi, bagi republikanisme merupakan pertanda politik mengalami kemunduran akibat invasi non-politis. Dengan demikian, kewarganegaraan republikanisme bertanggung jawab mengembalikan politik sebagaimana dimaksudkan dengan menekankan kepada manusia memiliki tanggung jawab sosial yang terberikan bahwa manusia harus merealisasikan tujuan-tujuan polis, yang salah satunya adalah mencapai kebahagiaan dalam suatu kebersamaan.

Kedua, civic virtue. Kewarganegaraan republikanisme berpendapat bahwa membentuk civic virtue merupakan cara paling penting untuk mempersiapkan warga negara memenuhi kewajibannya sebagai warga negara yang aktif dan baik sebuah republik. Republikanisme meletakkan tindakan nyata dengan basis moral publik sebagai tolok ukur mengenai siapa itu warga negara yang baik. Warga negara yang baik tidak dipandang dari status, 
kekayaan, etnis, dan pandangan religiusnya, tetapi dari kesetiaannya dalam memenuhi kewajibannya terhadap polis. Warga negara yang baik diukur dari seberapa jauh dia berani memenuhi common good.

Republikanisme juga menekankan bahwa meski telah tersedia sebuah sistem identifikasi hukum yang bersifat universal, penentuan kualitas warga tidak datang dari segi-segi eksklusif yang dia terima dalam hukum itu. Karakter dan tujuan kewargangeraan harus tetap harus dia dapatkan dari tindakan dan keterlibatannya. Tindakan dan keterlibatan yang didasari oleh kesukarelaan dan kapasitas untuk mengabdi kebaikan bersama.

\section{Pembubaran Hizbut Tahrir}

\section{Indonesia Ditinjau dari Perspektif}

Kewarganegaraan Liberal dan

\section{Kewarganegaraan Republik}

Salah satu hak individual yang pokok dalam kewarganegaraan liberal adalah hak berorganisasi. Hal ini juga diatur dalam Pasal 28 UUD Negara Republik Indonesia Tahun 1945 yang menyatakan Kemerdekaan berserikat dan berkumpul, mengeluarkan pikiran dengan lisan dan tulisan dan sebagainya ditetapkan dengan undang-undang.

Adapun dalam kewarganegaraan republikanisme, berorganisasi juga termasuk dalam hak karena adanya pendapat bahwa warga negara dan politik adalah satu kesatuan antara politik dan tindakan (subjek) politik. Dengan demikian, berorganisasi diartikan sebagai tindakan berkumpul atau berserikat untuk mencapai kebaikan bersama.

Berdasarkan dua hal tersebut, apakah pembubaran HTI bisa dibenarkan? Dasar hukum pembubaran HTI adalah Peraturan Pemerintah Pengganti Undang-undang Nomor 2 Tahun 2017 tentang Perubahan Atas Undang-Undang Nomor 17 Tahun 2013 Tentang Organisasi Kemasyarakatan.

Jika menganalisisnya menggunakan kewarganegaraan liberal, pembubaran itu tentunya tidak sah. Tujuan hukum menurut Locke adalah bukan untuk meniadakan atau mengekang, melainkan melestarikan dan memperluas kebebasan. Bagi penganut kewarganegaraan liberal, Perppu tersebut merupakan sarana mengekang atau meniadakan kebebasan, terutama kebebasan berorganisasi. Namun, jika kita membaca argumen atau rasional pembubaran organisasi massa sebagaimanya dinyatakan dalam Perppu tersebut:

a. bahwa terdapat organisasi kemasyarakatan tertentu yang dalam kegiatannya tidak sejalan 
dengan asas organisasi

kemasyarakatan sesuai dengan anggaran dasar organisasi kemasyarakatan yang telah terdaftar dan telah disahkan Pemerintah, dan bahkan secara faktual terbukti ada asas organisasi kemasyarakatan dan kegiatannya yang bertentangan dengan Pancasila dan UndangUndang Dasar Negara Republik Indonesia Tahun 1945;

b. bahwa Undang-Undang Nomor 17 Tahun 2013 tentang Organisasi Kemasyarakatan belum menganut asas cantrarius actus sehingga tidak efektif untuk menerapkan sanksi terhadap organisasi kemasyarakatan yang menganut, mengembangkan, serta menyebarkan ajaran atau paham yang bertentangan dengan Pancasila dan UndangUndang Dasar Negara Republik Indonesia Tahun 1945 (Pertimbangan huruf (d) dan (e) Peraturan Pemerintah Pengganti Undang-undang Nomor 2 Tahun 2017 tentang Perubahan Atas Undang-Undang Nomor 17 Tahun 2013 Tentang Organisasi Kemasyarakatan).
Dari alasan tersebut, organisasi massa bisa dibubarkan karena kegiatannya tidak sejalan dengan asas organisasi kemasyarakatan sesuai dengan anggarandasar organisasi kemasyarakatan yang telah terdaftar dan telah disahkanpemerintah, dan bahkan secara faktual terbukti ada asas organisasi kemasyarakatandan kegiatannya yang bertentangan dengan Pancasila dan Undang-Undang Dasar Negara Republik Indonesia Tahun 1945. Kewarganegaraan liberal memandang stabilitas masyarakat politik sepenuhnya dibebankan kepada negara sebagai regulator sekaligus penegak hukum. Dengan pendasaran demikian, tidaklah heran jika John Locke memasukkan kepatuhan individu terhadap negara sebagai kewajiban kewarganegaraan. Tanpa adanya kepatuhan, stabilitas masyarakat liberal akan sangat sulit dipertahankan.

Bagaimana dengan tradisi kewarganegaraan republikanisme dalam menyikapi masalah pembubaran organisasi massa? Macchiavelli menyatakan ide pokok republikanisme bersandar pada tiga hal pokok berikut: (1) kebaikan bersama merupakan kebijaksanaan dan sikap kenegarawanan, (2) kebebasan sebagai situasi nondependensi; dan (3) kesetiaan kepada 
keamanan, perdamaian, otonomi, dan antikorupsi (Robet dan Boli Tobi, 2014: 146).

Pertama, apakah pembubaran HTI merupakan kebaikan bersama sebagai kebijaksanaan dan sikap kenegarawanan. Seorang negarawan dalam pandangan Macchiavelli terdiri atas konsep-konsep virtù dan fortuna. Virtù berarti keterampilan atau kejantanan, berasal dari katavir, laki-laki, dalam bahasa Latin. Maknanya lain sekali darivirtue dalam bahasa Inggris, yang berarti kebaikan hati ataumoralitas baik. Dalam bahasa makalah ini, virtù dianggapkumpulan sumber daya yang dimiliki seseorang atau bisadiciptakan, dimobilisasi, dan dimanfaatkan untuk mencapaitujuannya selaku aktor politik (Liddle, 2011: 22).

Contoh-contoh virtù atau sumber daya politik yang disebutMachiavelli amat bervariasi. Antara lain: kepintaran dan keberanianstrategis dan taktis, ketelitian, ketegasan, reputasipemurah hati dan pemaaf, dukungan masyarakat sendiri,dukungan penguasa negara tetangga, kemampuan memilihpembantu dan kemampuan membaca tanda zaman. Juga, tentusaja: kelihaian dan kesediaan berdusta dan menggunakan kekerasansecara kejam dan berdarahdingin. Namun, terlepasdari rinciannya, perhatian Machiavelli pada sifat-sifat sangaktor yang berpikir dan bergerak merupakan sumbanganutamanya kepada pengetahuan kita mengenai dunia politik (Liddle, 2011: 23).

Fortuna berarti kans atau keberuntungan, tetapi dalampengertian kondisi-kondisi alamiah dan sosial serta kejadian-kejadianyang dihadapi penguasa atau calon penguasa tanpaimplikasi keharusan atau nasib (Liddle, 2011: 24).

Bisa dimengerti usaha mengeluarkan Perppu tersebut merupakan salah satu bentuk virtu karena Perppu sendiri bisa dimobilisasi sebagai sumber daya dukungan politik seorang pemimpin untuk membubarkan organisasi massa yang kegiatannya tidak sejalan dengan asas organisasi kemasyarakatan sesuai dengan anggarandasar organisasi kemasyarakatan yang telah terdaftar dan telah disahkanemerintah, dan bahkan secara faktual terbukti ada asas organisasi kemasyarakatandan kegiatannya yang bertentangan dengan Pancasila dan Undang-Undang Dasar Negara Republik Indonesia Tahun 1945. Berarti, dikeluarkan Perppu tersebut merupakan usaha pemimpin untuk terciptanya kebaikan bersama.

Kedua, kebebasan sebagai situasi non-dependensi. Sebagaimana sudah dijelaskan di atas, kebebasan sebagai 
situasi non-dependensi itu bisa hilang jika ada ancaman atau paksaan. Kebebasan berorganisasi, dalam konteks HTI, juga bisa hilang sebagaimana diatur dalam Pasal 59 Ayat (4) Perppu Nomor 2 Tahun 2017 tentang Perubahan Atas Undang-Undang Nomor 17 Tahun 2013 Tentang Organisasi Kemasyarakatan yang menyatakan:

(4) Ormas dilarang:

a. Menggunakan nama, lambang, bendera, atau simbol organisasi yang mempunyai persamaan pada pokoknya atau keseluruhannya dengan nama, lambang, bendera, atau simbol organisasi gerakan separatis atau organisasi terlarang;

b. melakukan kegiatan separatis yang mengancam kedaulatan Negara Kesatuan Republik Indonesia; dan/atau

c. menganut, mengembangkan, serta menyebarkan ajaran atau paham yang bertentangan dengan Pancasila.

Artinya, sebagai warga negara yang hidup dalam kerangka republikanisme, tujuan hidupnya adalah kebaikan bersama dalam artian tindakan. Jika HTI tidak melakukan tindakan yang sebagaimana sudah disebutkan di atas, pemerintah tidak akan membubarkan
HTI. Sebagaimana warga negara lain, HTI juga bisa mendapatkan jaminan hak atas kebebasan sebagai yang terberi, bukan dalam acuan metafisika, melainkan karena tindakannya. Jika tindakan HTI tidak melanggar segala ketentuan dalam Perppu atau kebaikan bersama rakyat Indonesia, HTI tetap memperoleh kebebasannya.

Ketiga, adanya kesetiaan warga negara kepada keamanan, perdamaian, otonomi, dan antikorupsi. Kesetiaan warga negara dalam kamus ilmu politik sering disebut patriotisme. Common good dan patriotisme dalam kewarganegaraan republik saling berhubungan. Macchiavelli menyatakan begitu common good rontok, seluruh atmosfer kepolitikan yang sehat dan baik juga runtuh, hubungan kewarganegaraan juga runtuh, dan politik tidak memiliki pendasarannya lagi. Oleh karena rasa kebersamaan hilang, perasaan bertanah air pun menjadi lemah.

Lebih lanjut, Macchiavelli menyatakan bahwa patriotisme tidak identik dengan heroisme atau militerisme. Baginya, patriotisme tidak tergantung kepada jabatan seorang, tetapi pada sikap virtuos terhadap common good. Dalam buku Discorsi, Macchiavelli menyatakan rasa patriotisme adalah sebuah kekuatan moral yang mendorong setiap warga 
negara mengejar pencapaian kebaikan bersama.

Seberapa bangga Ibu/Bapak menjadi warga Indonesia, Apakah Ibu/Bapak? ... (\%)

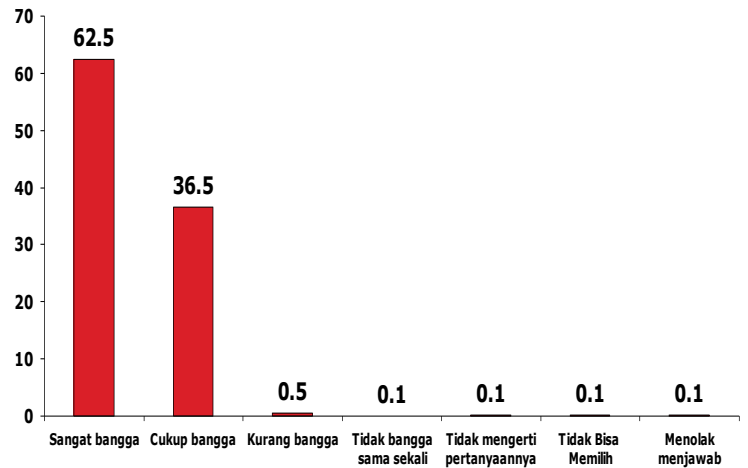

Grafik di atas merupakan survei Saiful Mujani Research and Consulting (SMRC) yang menyatakan bahwa masyarakat Indonesia sangat bangga menjadi WNI sebanyak $(62,5 \%)$.

Jika dikaitkan dengan pembubaran HTI, tentunya kita bisa mengambil contoh bahwa HTI yang berarti Partai Pembebasan dalam bahasa Arab, adalah sebuah organisasi internasional yang bekerja untuk pembangunan kembali kekhalifahan, sistem global dari pemerintahan Muslim yang terakhir ada di bawah kerajaan Usmani. Cita-cita organisasi massa HTI tidaklah sejalan dengan bangsa Indonesia yang menganut Pancasila dan UUD Negara Republik Indonesia Tahun 1945. Jika tidak sejalan dengan cita-cita, bisa dianggap patriotisme anggota HTI sangatlah kurang.

Jika kita merujuk survei SMRC, banyak masyarakat Indonesia yang tidak setuju bentuk negara Indonesia berdasarkan khalifah yang merupakan tujuan organisasi HTI.

Dalam masyarakat ada kelompok warga yang menginginkan Negara Kesatuan Republik Indonesia (NKRI) yang bersandar pada Pancasila dan UUD 1945 diubah menjadi khilafah atau negara Islam yang bersandar pada al-Qur'an, hadis, dan pendapat ulama tertentu. Tapi ada juga yang berpendapat bahwa NKRI yang bersandar pada Pancasila dan UUD 1945 itu adalah yang terbaik bagi rakyat Indonesia karena tidak semua rakyat Indonesia beragama Islam, dan di antara yang beragama Islampun tidak semua sama faham dan alirannya. Pada pendapat mana Ibu/Bapak setuju? ... (\%)

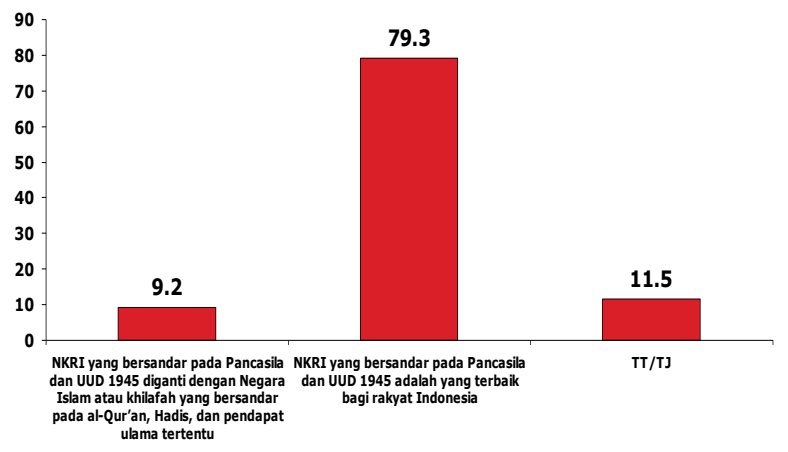

\section{KESIMPULAN}

Hak individual yang pokok dalam kewarganegaraan liberal adalah hak berorganisasi, sedangkan kewarganegaraan republikanisme, berorganisasi juga termasuk dalam hak karena adanya pendapat bahwa warga negara dan politik adalah satu kesatuan antara politik dan tindakan (subjek) politik. Jika menganalisisnya menggunakan kewarganegaraan liberal, pembubaran itu tentunya tidak sah, karena Perppu tersebut merupakan sarana mengekang atau meniadakan kebebasan, terutama kebebasan 
berorganisasi. Tetapi bagi kewarganegaraan republikanisme, HTI adalah sebuah organisasi internasional yang bekerja untuk pembangunan kembali kekhalifahan, sistem global dari pemerintahan Muslim yang terakhir ada di bawah kerajaan Usmani. Cita-cita organisasi massa HTI tidaklah sejalan dengan bangsa Indonesia yang menganut Pancasila dan UUD Negara Republik Indonesia Tahun 1945. Jika tidak sejalan dengan cita-cita, bisa dianggap patriotisme anggota HTI sangatlah kurang.

\section{A. Saran}

Diperlukan adanya Peraturan Perundang-undangan yang lebih lanjut untuk mengatur organisasi, dikarenakan Undang-Undang Nomor 17 Tahun 2013 tentang Organisasi Kemasyarakatan belum menganut asas cantrarius actus sehingga tidak efektif untuk menerapkan sanksi terhadap organisasi kemasyarakatan yang menganut, mengembangkan, serta menyebarkan ajaran atau paham yang bertentangan dengan Pancasila dan Undang-Undang Dasar Negara Republik Indonesia Tahun 1945 (Pertimbangan huruf (d) dan (e) Peraturan Pemerintah Pengganti Undang-undang Nomor 2 Tahun 2017 tentang Perubahan Atas Undang-Undang Nomor 17 Tahun 2013 Tentang Organisasi Kemasyarakatan).

\section{DAFTAR PUSTAKA}

Bayu Dwi Anggono, 24 Mei 2017, Meninjau Alasan Hukum Pembubaran HTI, https://news.detik.com/kolom/3510 278/meninjau-alasan-hukumpembubaran-hti.

LarryDiamond, "Toward Democratic Consolidation," Journal of Democracy, Vol. 5, No. 3 (1994)

Mohamed Nawab Mohamed Osman, "The Transnational Network of Hizbut Tahrir Indonesia," Southeast Asia Research, Vol. 18, No. 4 (Desember 2010)

Peter Mahmud Marzuki, 2014, Penelitian Hukum,Jakarta,

Kencana Prenada Media Group.

R. William Liddle. 2011. Memperbaiki

Mutu Demokrasi Di Indonesia Sebuah Perdebatan. Jakarta: Pusat Studi Agama \& Demokrasi (PUSAD) Yayasan Wakaf

Paramadina

Robertus Robet dan Hendrik Boli Tobi. 2014. Pengantar Sosiologi Kewarganegaraan dari Marx sampai Agamben. Jakarta: Marjin Kiri

Sidney Jones. 2013. Sisi Gelap Reformasi di Indonesia: 
Munculnya Kelompok Masyarakat

Madani Intoleran. Disampaikan sebagai Nurcholish Madjid Memorial Lecture (NMML) di Aula Nurcholish Madjid, Kampus Universitas Paramadina, Jakarta, 19 Desember 2013.

Saiful Mujani Research and Consulting. NKRI dan ISIS: Penilaian Massa Publik Nasional. Temuan Survei Mei 2017

Thomas Janoski dan Brian Grann, "Political Citizenship: Foundation of Rights", dalam Engin F. Isin dan Bryan S. Turnet (eds),
Handbook of Citizenship Studies (London: Sage, 2002)

Peraturan Pemerintah Pengganti Undang-undang Nomor 2 Tahun 2017 tentang Perubahan Atas Undang-Undang Nomor 17 Tahun 2013 Tentang Organisasi Kemasyarakatan

Undang-Undang Nomor 17 Tahun 2013 Tentang Organisasi Kemasyarakatan.

Wikipedia, Pembubaran Hizbut Tahris Indonesia,

https://id.wikipedia.org/wiki/Pemb ubaran_Hizbut_Tahrir_Indonesia. 